\title{
Schizophrenia: A Neurodevelopmental Perspective
}

Lym S. Pilowsky, B.M., B.S., M.R.C. Psych., Robert W. Kerwin, M.A., Ph.D., M.R.C. Psych., and Robin M. Murray, F.R.C. Psych.

The role of aberrant neurodevelopment in the etiology of schizophrenia is reviewed in light of recent murpathologic, neurochemical, and neuroimaging aidence of cerebral abnormalities in schizophrenic rimts. There may exist some genetic defect in the ontrol of brain development. Clinical epidemiologic srocys highlight the importance of obstetric amplications, and prenatal exposure to influenza epidemics in contributing to these abnormalities. It is suggested that such environmental hazards and aberrations in the control of early brain development produce the neuronal phenotype that manifests as schizophrenia with early age of onset of symptoms associated with soft neurologic signs and is more common in young males. [Neuropsychopharmacology 9:83-91, 1993]
Tr wORDs: Schizophrenia; Neurodevelopment; Etiology; Nuropathology; Epidemiology; Neuroimaging

The understanding of schizophrenia as primarily a brain fisorder, first postulated by Kraepelin, receded in the 150 s and 1960 s, but has emerged strongly in the last wade. There is now a plethora of studies that describe mroanatomic, neurochemical, and neurophysiologic thormalities in schizophrenic patients (Johnstone et d. 1976; Reynolds 1983; Bogerts et al. 1985; Benes et d. 1986; Jakob and Beckmann 1986; Bruton et al. 1990).

Recent research has suggested that these abnormallies may be developmental rather than degenerative morigin. Here, the role of aberrant neurodevelopment inschizophrenia will be evaluated by considering evimee from neuropathologic, neuroimaging, and neuwhemical studies, as well as epidemiologic surveys

Fon the Genetics Section (LSP), and Genetics and Neurosciences Suions (RWK), Institute of Psychiatry, De Crespigny Park, London; dhe Department of Psychological Medicine and Genetics Section CMM, King's College Hospital and Institute of Psychiatry, De Copizny Park, London.

Address correspondence to: Dr. L. S. Pilowsky, Genetics Section, itute of Psychiatry, De Crespigny Park, Denmark Hill, London IDBAF.

Lavived May 5, 1992; revised November 24, 1992; accepted January a.m. of obstetric complications and date of birth in schizophrenic patients compared to normal controls.

\section{NEUROPATHOLOGIC EVIDENCE}

Although neuropathologic abnormalities were first reported in schizophrenia in the late 1800 s and early 1900s (Alzheimer 1897; Wernicke 1900; Klippel and Lhermitte 1909), for the first half of this century the evidence supporting their presence was conflicting. Postmortem research was beset by problems, both clinical and scientific. These included inadequate case definition, sampling errors, contamination by effects of treatment, poor controls, and histologic artifact. Early studies also concentrated on cortical rather than subcortical structures. Recently, with improved methods, closer diagnostic agreement and the systematic collection and examination of brains from untreated schizophrenic patients, some consistent findings have emerged. In three well-conducted studies, schizophrenic brains showed a slight but significant decrease in weight and length (Brown et al. 1986; Pakkenberg 1987; Bruton et al. 1990) compared to normal controls. Bogerts et al. (1985) demonstrated a $20 \%$ to $30 \%$ decrease in the volume of the medial temporal lobe (amyg- 
dala, hippocampus, and parahippocampal gyrus). This finding fits with evidence of particular enlargement of the temporal horn of the lateral ventricle (Brown et al. 1986).

Falkai and Bogerts (1986), in the first use of quantitative cytology applied to this context, demonstrated decreased cell counts in the hippocampus, and in a further study, also found a reduction in volume of the entorhinal cortex along with decreased numbers of neurons (Falkai et al. 1988). Jeste and Lohr (1989) compared schizophrenic with nonschizophrenic patients and normal controls and found a decrease in hippocampal pyramidal cell density with a loss of hippocampal volume in the schizophrenic patients. Benes et al. (1986) reported decreases in neuronal density in other cortical areas (prefrontal cortex, cingulate cortex, and motor cortex). Since gliosis would indicate neuronal injury or degeneration, its absence in many, although not all, schizophrenic patients together with decreases in neuronal counts points to developmental aberrations (Roberts et al. 1987).

Abnormal cell migration during development has also been implicated, because if this process is disrupted, abnormalities in cell position rather than cell number are found (Nowakowski 1987). Deviations in cerebral cytoarchitecture with abnormal cell positioning have been described in schizophrenic brains (Kovelman and Scheibel 1984; Altschuler et al. 1987); however, a recent study did not replicate these findings (Christison et al. 1989). Conrad et al. (1991) showed hippocampalcell disorganization in the left and right hemispheres of 10 schizophrenic patients. Jakob and Beckmann (1986) reported abnormalities in layer II of the entorhinal cortex with displacement of some of the cells into layer III.

Other neuropathologic evidence, however, mitigates against a solely prenatal explanation for all the lesions found in schizophrenic brains. In earlier work, gliosis was often reported in schizophrenia (Winkelman and Book 1949; Stevens 1982) and more recently, Bruton et al. (1990) found that a surprisingly large number of schizophrenic brains showed focal pathology compared to controls (40\%). In patients with focal pathology, fibrillary gliosis was also found affecting the cerebral cortex, the white matter, and periventricular regions. This leads us to conclude that in those patients with focal pathology, either the damage was acquired as a reactive response to cerebral insult or may represent secondary vulnerability to damage due to underlying structural changes (Roberts 1991).

Thus, neuropathologic findings appear to demonstrate multiple lesions in schizophrenic brains, some of which may have a developmental explanation. Just how these lesions arise is yet to be precisely defined. Researchers have postulated abnormalities in fetal cell proliferation and migration (Nowakowski 1987; Murray et al. 1988) due to genetic factors or environmental insult. Interference with the normal process of selective neuronal death during early life leading to axonal disorganization and neuronal misconnections has also been suggested (Benes et al. 1986; Goodman 1989; Lewis et al. 1989).

\section{NEUROIMAGING EVIDENCE}

\section{Structural Findings}

The evidence of brain abnormalities in schizophrenic patients found by recent neuropathologic research has received support from neuroimaging studies. Pneumoencephalographic investigation (Jacobi and Winkler 1927; Lempke 1935; Huber 1957) were the first to reveal ventricular enlargement in schizophrenic patients which remained static over a 20-year follow-up period (Huber et al. 1985). These nonprogressive changes were related to the clinical defect state of personality disintegration and poor outcome and were thought by these investigators to be congenital in origin.

Computerized Tomography Studies. Computerized tomography (CT) studies substantiated the earlier findings. Johnstone et al. (1976) and others (Nasrallah et al. 1982) demonstrated ventriculomegaly. This is present at the onset of positive symptoms (Schulz et al. 1983; Turner et al. 1986) and in some cases before florid illness emerged (O'Callaghan et al. 1988). These changes have also been shown to be nonprogressive (Illowsky et al. 1988; Vita et al., 1988). The prevalence of ventricular enlargement in schizophrenic patients is unclear and is clouded by the fact that different research groups have used varying cut-off points to distinguish normal from enlarged ventricles (Andreasen et al. 1982); they have also examined different types of patients, either chronically or acutely ill. The specificity of the changes to schizophrenia has been questioned. Har. vey et al. (1990) performed a CT scan study of 72 patients compared to 50 community controls. Of the patients, 37 were diagnosed schizophrenic, 15 schizoaffective, 11 bipolar, 5 major depression, and 4 unspecified psychosis. Schizophrenics showed enlarged ventricles but there was no diagnostic specificity for increased ventricular-brain ratio (VBR); the lateral ventricular sizeof bipolar patients lay between that of schizophrenics and normal controls.

It appears from the above, that there is a subgroup of schizophrenic patients in whom enlarged ventricles have been clearly documented. The task for investigz tors has been to clearly define this group on epidemiologic, clinical, and neuropsychologic parameters. If CT changes can be correlated with these clinical indicesit may help explain the origin of the abnormalities. 
CTStudies and Clinical Parameters. Increases in VBR have been associated with evidence of premorbid psychopathology (Weinberger et al. 1980). There is some evidence that structural abnormalities relate to poor premorbid adjustment and many, but not all, studies report a relationship with neuropsychologic impairment (Crow 1985). Johnstone et al. (1989a) demonstrated that cognitive impairment was significantly related to brain area in early onset but not in late onset cases. The former group of patients are far more likely w be male and to have shown personality and cognitivedeficits in childhood (Aylward et al. 1984; Foerster t al. 1991). Foerster et al. (1991) point out the similarin between this male predominance and that in neurodevelopmental disorders such as autism and dyslexia.

Comparisons between "familial" and "nonfamilial" schizophrenic patients have been made to determine whether there is an excess of $\mathrm{CT}$ abnormalities in those individuals not at high genetic risk. Harvey and Murny (1990) reviewed the evidence. Of 16 singleton sudies, 9 were acceptable methodologically. Three sudies found no relationship between VBR and famWhistory (Farmer et al. 1987; Williams et al. 1985; Weinberger et al. 1981), whereas others supported ventricuIr abnormalities as being more common in the population of patients not obviously at high genetic risk (Tumer et al. 1986; Owen et al. 1989; Reveley and Chitura 1985). The issue was confused by the inclusion in one studies of probands whose relatives had affective pychosis rather than only those whose relatives were xhizophrenic. Indeed, Owen et al. (1989) in a case contolstudy, reported that schizophrenic probands with in affectively ill relative differed from other schizophrenic probands in having no evidence of ventricular alargement. Thus it would be premature to draw condusions on the nature of CT changes in familial or sporadic subgroups based on currently available evidence until further, better controlled studies become wailable.

Megnetic Resonance Studies. Magnetic resonance imging (MRI) studies have not only confirmed the CT tndings of enlarged ventricles in schizophrenic patients but have also shown smaller volume of brain structures, inparticular the temporal lobe and hippocampus (Suddeth et al. 1990; Bogerts et al. 1990; Andreasen et al. 1986; Johnstone et al. 1989b). Harvey et al. (1992) mported a generalized decrease in cortical volume in shizophrenics compared with controls, suggesting that the temporal lobe findings are simply one manifestaion of a more diffuse process affecting cortical grey matvr. Bogerts et al. (1990) also noted that hippocampal rolume was significantly smaller in the left hemisphere of male patients. Gur et al. (1991), in an MRI volumet$\dot{x}$ analysis of brain and cerebrospinal fluid (CSF) in 47 schizophrenic patients and 47 controls, found higher ratios of sulcal CSF to cranial volume in male but not female schizophrenic patients compared to controls. This is in accord with much other evidence of greater structural abnormalities in males than in female schizophrenics (Castle and Murray 1991).

Studies of Discordant Twins. Twin strategies have been particularly useful in trying to disentangle whether neuroimaging abnormalities are genetic or acquired. As monozygotic (MZ) twins are genetically identical, differences between them must be due, at least in part, to environmental factors. A study using the Maudsley twin register showed that ventricular size was strongly genetically determined in a series of healthy $M Z$ twin pairs, and that the correlation in ventricular size was lower in $\mathrm{MZ}$ pairs discordant for schizophrenia. Furthermore, the schizophrenic twins had significantly larger ventricles than their nonschizophrenic cotwins (Reveley et al. 1982; Murray et al. 1985b). Interestingly, the nonschizophrenic cotwins had larger ventricles than those of $\mathrm{MZ}$ twins from completely normal pairs. This suggests that an environmental factor caused increase in ventricular size in both members of the discordant pair, only the more severely affected twin becoming schizophrenic.

An MRI study of 15 pairs of $M Z$ twins discordant for schizophrenia confirmed increased ventricular size (particularly in the lateral ventricles and the third ventricle) in the affected twins, as well as loss of hippocampal volume on the left and right in affected compared to nonaffected cotwins. No such intrapair differences were found in seven pairs of control twins (Suddath et al. 1990). The findings of these two twin studies add support to acquired rather than genetic factors being of etiological importance, at least in the twin population. Environmental pre- or perinatal factors may of course be more important in schizophrenic twins than schizophrenic singletons because of the greater liability of twins to obstetric complications. To reinforce caution in extending twin findings to the general schizophrenic population, Lewis et al. (1990) reported an intriguing case of identical twins in whom the schizophrenic twin showed no brain abnormalities on MRI but the unaffected twin had extensive right temporal damage of congenital origin.

\section{Functional Findings}

The last decade has witnessed great advances in imaging techniques measuring brain function in the living human (positron emission tomography [PET] and single photon emission tomography [SPET]). It is now possible to examine brain metabolism, cerebral blood flow (tightly coupled with brain metabolism), and a variety 
of neurotransmitter receptors. Applying these techniques, it may be possible to correlate structural with functional deficits, and assess whether functional abnormalities are the cause or consequence of structural lesions. This is a burgeoning research area that will not be discussed in depth here.

Early PET investigations found decreased frontal cortical glucose metabolism and blood flow (Ingvar and Franzen 1974; Farkas et al. 1984; Buchsbaum et al. 1982). However, the evidence regarding "hypofrontality" in schizophrenic patients remains conflicting because there are many methodologic and technical differences between studies which have not been systematically addressed. Inability to activate the frontal cortex when performing a task-activating condition is said to occur mainly in schizophrenics with predominantly negative symptoms (Garza-Trevino et al. 1990).

Weinberger (1987) asserts that there is evidence of a decrease in cerebral flood flow during mental activity in the left dorsolateral prefrontal cortex in schizophrenics compared to healthy normals (Weinberger et al. 1986; Berman et al. 1986). On the basis of animal studies and the cerebral blood flow pattern in schizophrenics, he implicates this site as a seat of dysfunction in schizophrenia. This is of particular interest as prenatal lesions of the dorsolateral prefrontial cortex in primates are behaviorally silent until the animal reaches the equivalent of human adolescence (Goldman-Rakic 1987). Since these studies, other investigators using PET and SPET have shown deficits particularly in left frontal cortical and temporal blood flow, at rest and during specific neuropsychologic tasks (Liddle et al. 1992; Lewis et al. 1992). Intriguing findings of a left lateralized increase in globus pallidus blood flow and striatal $\mathrm{D}_{2}$ receptor density in patients compared to controls (Early et al. 1989; Farde et al. 1990; Pilowsky et al. 1993) also suggest disruption of frontostriatolimbic circuits in some patients with schizophrenia. Furthermore, the normal decrement in striatal $D_{2}$ receptors with age appears to be lost in schizophrenic patients (Martinot et al. 1990, 1991; Pilowsky et al. 1993), which may be evidence of dysfunctional cerebral maturation. These abnormalities may therefore provide a clue to underlying mechanisms amenable to investigation.

\section{CLINICAL EPIDEMIOLOGY}

Geneticfactors are well known to operate in schizophrenia, perhaps by some defect in the control of neurodevelopment (Jones and Murray 1991). However, environmental factors are likely also to be of etiological importance. Schizophrenic patients are more likely than healthy controls and other psychiatric patients to have a history of pre- and perinatal hazards and to be born premature. Henceforth the term obstetric complications is taken to refer to deviations from normal pregnancy, delivery, and early neonatal period (McNeil and Kaij 1978; Lewis and Murray 1987). Most recently, Eagles et al. (1990) studied schizophrenic patients using their healthy siblings as controls. They standardized criteria to diagnose schizophrenia and to scrutinize birth records blind to adult outcome, thus overcoming many of the methodologic shortcomings of previous studies. They found a strongly significant excess of obstetric complications in schizophrenics compared to healthy controls (although no single complication was particularly implicated). Such complications appear particularly in the histories of male schizophrenics, are as. sociated with early age of onset, and with increased ventricular size (Lewis et al. 1989; Castle and Murray 1991).

A history of an affected relative and a history of obstetric complications tend to segregate separately, sug. gesting that some early cerebral insult such as hypoxia may induce phenocopies in those individuals less predisposed genetically (Murray et al. 1988). This argument gains support from the fact that the pyramidal cells in the hippocampus - an area known to be damaged in schizophrenia - are extremely vulnerable to cerebral anoxic insult, such as that which may occur during a difficult pregnancy and delivery.

Perinatal complications may explain the occurrence of schizophrenia in some patients but do not account for all the developmental abnormalities found. Foerster et al. (1990) reported that schizophrenic patients had a lower mean birth weight than controls and Lewis et al. (1987) noted that MZ twins discordant for psy. chosis already showed greater intrapair differences in weight at birth than normal MZ pairs. McNeil (1993) reported significantly smaller head circumference at birth in preschizophrenic patients than normal controls with disproportionately small head size in relation to shoulder width. Small head size occurred preferentially in sporadic schizophrenics but was not associated with obstetric complications. Of course, fetal abnormalities could, in themselves, contribute to difficult deliveries and obstetric complications.

These findings suggest abnormalities in development that antedate the perinatal period. Furthermore, other indicators of developmental disruption during fe tal life such as minor physical anomalies are present in excess in schizophrenic patients compared to normal controls (Green et al. 1989). Again, minor physicd anomalies are more common in male schizophrenic, predict a younger age of onset, and are associated with cognitive impairment (Green et al. 1987; Waddington et al. 1990). This is also consistent with the notion the early-onset schizophrenia involves a more compro mised central nervous system and may constitute asep. arate subgroup of patients.

Schizophrenics are born slightly more often in the 
bte winter and spring. This winter excess is not explained by seasonal variation in obstetric complications (0'Callaghan et al. 1991) but investigators have linked the excess of winter birth to viral infection. Mednick tal. (1988) reported on a Finnish birth cohort in which it was found that those in the second trimester of fetal development during the 1957 type A2 influenza epidenic ("Asian flu") were at elevated risk of subsequently being admitted to a psychiatric hospital with adiagnosis of schizophrenia. These authors postulated that a viral infection could disrupt the process of cell migration from the ventricular zone to the neocortex, which occurs around 16 to 24 weeks of gestation. A much larger study from England has since replicated this finding (O'Callaghan et al. 1991).

The schizophrenogenic effects of influenza do not spear to be confined to the "Asian flu" pandemic. Studies in Denmark (Barr et al. 1990) and England (Sham et al. 1991) over 4 and 2 decades, respectively, have shown a consistent rise in schizophrenic births der influenza epidemics. It is not clear whether the tiological factor is influenza specific, or whether other bators, such as maternal pyrexia, commercial mediines, or other associated stresses could be responsiHe. However Conrad and Scheibel (1987) claim that muraminidase-containing viruses such as influenza can interfere with intercellular adhesiveness required for mooth migration of developing hippocampal neurons Nowakowski 1987). Scheibel et al. (1991) have recently daimed that pregnant mice who they infected with ituenza produced offspring with hippocampal cell disray reminiscent of that which these authors earlier reported in schizophrenia (Kovelman and Scheibel 14). Cortical abnormalities were widespread in these nimals, which is perhaps consistent with neuropathobgic findings of increased focal neuropathology in thizophrenic patients (Bruton et al. 1990), but caution isequired in extrapolating etiological mechanisms from peliminary animal models.

\section{DEVELOPMENTAL NEUROCHEMISTRY}

The neurochemistry of schizophrenia has been substanively reviewed in the literature and will not be disassed in depth. In terms of neurodevelopmental infuences, the focus here will be on excitatory neumonsmitters and trophic factors rather than monominergic systems. Kerwin and Murray (1992) provide Idetailed overview of the area.

The neurotransmitter cholecystokinin (CCK) is ighly concentrated in the hippocampus (Roberts et al. DA) and is reduced in this region in schizophrenic hins (Crow et al. 1982; Roberts et al. 1983; Ferrier et d. 1983; Carruthers et al. 1984), whereas cortical CCK eens unchanged (Perry et al. 1981). The hippocampal reduction in CCK has been associated with negative symptoms (Roberts et al. 1983). Excitatory amino acid levels in the temporal region are alsodiminished, with a loss of glutamergic terminals (Deakin et al. 1989); in addition, bilateral loss of $\left[{ }^{3} \mathrm{H}\right]$ kainate binding localized in the CA4/CA3 region and inner layers of the entorhinal cortex has been demonstrated (Kerwin et al. 1990).

The above neurotransmitter systems have been found to play a role as trophic factors in hippocampal development. Glutamate and N-methyl-D-aspartate have been shown to stimulate the formation of tau in axons, cell bodies, and dendrites (Mattson et al. 1988). N-Methyl-D-aspartate receptors are vital to the expression of a variety of experience-dependent synaptic remodeling processes (Harris et al. 1984; Kleinschmidt et al. 1987; Bear et al. 1990), and Mattson et al. (1990) have proposed that fine tuning of glutamate systems is primarily responsible for the maintenance and modulation of neuronal architecture. A deficit of these substances in the hippocampus may result in aberrant cell growth in the hippocampus. Alternatively, it is well established that excitatory amino acid receptors mediate some pathophysiologic consequences of ischemia (Collins 1986) and that psychotomimetic antagonists such as phencyclidine and $\mathrm{MK}-801$ can protect against this (Lyeth et al. 1989). It is therefore possible that these excitatory amino acids play a part in mediating the cerebral damage resulting from pre- or perinatal hypoxia.

The CCK receptors are also important in hippocampal development. The CCK receptor number fluctuates during fetal brain development and in the early postnatal period (Hays et al. 1981). Cells containing CCK are arranged in a laminar fashion that could influence the attraction of ingrowing afferents (Chun et al. 1987). Underexpression of CCK receptors, as is found in schizophrenia, could result in the disturbance of cell migration such as is seen in schizophrenia (Kerwin and Murray 1992).

\section{AN ETIOLOGICAL MODEL}

Murray and coworkers (1985a, 1988) have contended that schizophrenia is a heterogenous condition with a number of different causes. The condition that most closely approximates Kraepelin's dementia praecox (i.e., schizophrenia of early onset, more common in males, and associated with neurologic soft signs and cognitive impairment) is likely to be the consequence of aberrant neuronal development during pregnancy and the neonatal period. It is associated with a variety of macro- and microscopic abnormalities including increased ventricular size, cortical (especially temporal) dysplasia, and disordered hippocampal cytoarchitecture. The nonprogressive nature of these changes suggests that they are developmental anomalies which may 
be consequent upon inheritance of mutant genes, fetal, or neonatal adversity or a combination of the two. The question of why florid psychotic symptoms do not develop until early adulthood has led researchers to speculate that the neural dysplasia remains quiescent until it is unmasked by brain maturational changes, possibly synaptic pruning or myelination (Murray et al. 1988; Benes 1989; Pilowsky and Murray 1991).

Developmental theories do not account for other types of schizophrenia, for example, late onset, or transient, good prognosis illnesses. These illnesses occur particularly in women and in those with a relative suffering from affective disorder; such individuals may have a disorder that has more in common etiologically with affective disorder. Indeed, Murray and O'Callaghan (1991) suggest that the Kraepelinian distinction between schizophrenic and manic-depressive psychosis should be abandoned in favor of a distinction between psychosis of neurodevelopmental and adult origin.

\section{REFERENCES}

Altshuler LL, Conrad A, Kovelman JA, Scheibel A (1987): Hippocampal pyramidal cell orientation in schizophrenia, a controlled neurohistologic study of the Yakovlev collection. Arch Gen Psychiatry 44:1094-1098

Alzheimer A (1897): Beitrage zur pathologischen anatomie der hirnrinde und zur anatomischen grunlage der psychosen. Monatsschrift Psychiatr Neurol 2:82-120

Andreasen NC, Smith MR, Jacoby CG, Dennert JW, Olsen SA (1982): Ventricular enlargement in schizophrenia, definition and prevalence. Am J Psychiatry 139:292-296

Andreasen NC, Nasrallah HA, Dunn V, Olson SC, Grove WM, Erhardt JC, Coffman JA, Crossett JHW (1986): Structural abnormalities in the frontal system in schizophrenia. A magnetic resonance imaging study. Arch Gen Psychiatry 43:136-144

Aylward E, Walker E, Bettes B (1984): Intelligence in schizophrenia: Meta-analysis of the research. Schizophren Bull, 10:430-459

Barr CE, Sarnoff A, Mednick DM, Munk-Jorgensen MD (1990): Exposure to influenza epidemics during gestation and adult schizophrenia-a 40-year study. Arch Gen Psychiatry 47:869-874

Bear MF, Kleinschmidt A, Gu Q, Singer W (1990): Disruption of experience dependent synaptic modifications in striate cortex by infusion of an NMDA receptor antagonist. J Neurosci 10:909-925

Benes FM (1989): Myelination of cortical hippocampal relays during late adolescence. Schizophren Bull 15:585-593

Benes FM, Davison J, Bird ED (1986): Quantitative cytoarchitectural studies of the cerebral cortex in schizophrenics. Arch Gen Psychiatry 43:31-35

Berman KF, Zec RF, Weinberger DR (1986): Physiologic dysfunction of dorsolateral prefrontal cortex in schizophrenia. II. Role of neuroleptictreatment, attention and mental effort. Arch Gen Psychiatry 43:126-143
Besson JAO, Corrigan FM, Cherryman GR, Smith FW (1987): Nuclear magnetic resonance brain imaging in chronic schizophrenia. Br J Psychiatry 150:161-163

Bogerts B, Meertz E, Schonfeldt-Bausch R (1985): Basal ganglia and limbic system pathology in schizophrenia: A morphometric study of brain volume and shrinkage. Arch Gen Psychiatry 42:784-791

Bogerts B, Ashtari M, Degreef G, Alvir J, Bilder RM, Lieberman JA (1990): Reduced temporal limbic structure volumes on magnetic resonance images in first episode schizophrenia. Psychiatry Res 35:1-13

Brown R, Colter M, Corsellis JAN, Crow TJ, Frith CD, John. stone EC, Owens DGC, Roberts GW (1986): Postmortem evidence of structural brain changes in schizophrenia. Arch Gen Psychiatry 43:36-42

Bruton CJ, Crow TJ, Frith CD, Johnstone EC, Owens DCC, Roberts GW (1990): Schizophrenia and the brain. Psychol Med 20:285-304

Buchsbaum M, Ingvar D, Kessler R (1982): Cerebral glucography with positron tomography: Use in normal subjects and in patients with schizophrenia. Arch Gen Psychiatry 39:251-259

Carruthers B, Dawbarn D, de Quidt M, Emson PC, Hunter J, Reynolds GP (1984): Changes in the neuropeptide content of amygdala in schizophrenia. Br J Pharmacol 81:139 (Abstract)

Castle D, Murray RM (1991): The neurodevelopmental basis of sex differences in schizophrenia. Psychol Med 21: 565-575

Christison GW, Casanova MF, Rawlings R, Kleinman IC (1989): A quantitative investigation of hippocampal pyramidal cell size, shape and variability of orientation in schizophrenia. Arch Gen Psychiatry 46:1027-1032

Chun JJM, Nakamura MJ, Shatz CJ (1987): Transient cells of the developing mammalian telencephalon are peptide immunoreactive neurons. Nature 325:617-620

Collins RC (1986): Selective vulnerability of the brain. New insights from the excitatory synapse. Metab Brain Dis 1:231-240

Conrad AJ, Scheibel AB (1987): Schizophrenia and the hip. pocampus. The embryological hypothesis extended. Schizophren Bull 13:577-587

Conrad AJ, Abebe T, Austin R, Forsythe S, Scheibel AB (1991): Hippocampal pyramidal cell disarray in schizophrenis as a bilateral phenomenon. Arch Gen Psychiatry 48: 413-417

Crow TJ (1985): The two syndrome concept: Origins and cu. rent status. Schizophren Bull 11:471-485

Crow TJ, Ferrier LN, Johnstone EC, Owens DGC, Roberts GW, Lee YC, Bloom SR, Polak JM (1982): Neuroendo. crine aspects of schizophrenia. In Finkand G, Whalleg LL (Eds), Neuropeptides: Basic and Clinical Aspets Edinburgh, Churchill Livingston, pp 222-239

Deakin JFW, Slater P, Simpson MDC, Gilchrist AC, Skan W/ Royston MC, Reynolds GP, Cross AJ (1989): Frontalca. tical and left temporal glutamatergic dysfunction i schizophrenia. J Neurochem 52:1781-1786

Eagles JM, Gibson I, Bremner MH, Clunie F, Ebmeier IP Smith NC (1990): Obstetric complications in DSM-I schizophrenics and their siblings. Lancet 335:1139-110 
Errly T, Posner M, Reiman EM, Raichle ME (1989): Hyperactivity of the left striatopallidal projection. Part 1: Lower level theory. Psychiat Dev 2:85-108

Falkai P, Bogerts B (1986): Cell loss in the hippocampus of schizophrenics. Eur Arch Psychiatry Neurol Sci 236: 154-161

Falkai P, Bogerts B, Rozumek M (1988): Limbic pathology in schizophrenia. The entorhinal region-a morphometric study. Biol Psychiatry 24:515-521

Farde L, Wiesel F-A, Stone-Elander S, Halldin C, Nordstrom A-L, Hall H, Sedvall G (1990): D2 dopamine receptors in neuroleptic naive schizophrenic patients. Arch Gen Psychiatry 47:213-219

Farkas T, Wolf A, Jaeger J, Brodie JD, Christman DR, Fowler IS (1984) Regional brain glucose metabolism in chronic schizophrenia. Arch Gen Psychiatry 41:293-300

Farmer A, Jackson R, McGuffin P, Storey P (1987): Cerebral ventricular enlargement in chronic schizophrenia. $\mathrm{Br} \mathrm{J}$ Psychiatry 150:324-330

Rerier IN, Roberts GW, Crow TJ, Johnstone EC, Owens DGC, Lee YC, O'Shaughnessy D, Adrian TE, Polak JM, Bloom SR(1983): Reduced cholecystokinin line and somatostatin line immunoreactivity in limbic lobe is associated with negative symptoms in schizophrenia. Life Sci 33:475-482

foerster A, Lewis S, Owen M, Murray RM (1991): How birth weight and a family history of schizophrenia predict poor premorbid functioning in psychosis. Schizophr Res 5:3-20

Grza-Trevino ES, Volkow ND, Cancrok R, Contreras S (1990): Neurobiology of schizophrenic syndromes. Hosp Commun Psychiatry 41:971-980

Coldman-Rakic PS (1987): Development of cortical circuitry and cognitive function. Child Dev 58:601-622

Coodman RN (1989): Neuronal misconnections and psychiatric disorder. Is there a link? Br J Psychiatry 154: 292-299

Geen MF, Satz P, Soper HV, Kharabi F (1987): Relationship between physical anomalies and age of onset of schizophrenia. Am J Psychiatry 144:666-667

Gren MF, Satz P, Gaier DJ, Ganzell S, Kharabi F (1989): Minor physical anomalies in schizophrenia. Schizophr Bull 15:91-99

Gur RE, Mozley PD, Resnick SM, Shtasel D, Kohn M, Zimmerman R, Herman G, Atlas S, Grossman R, Erwin R, Cur RC (1991): Magnetic resonance imaging in schizophrenia. I. Volumetric analysis of brain and cerebrospinal fluid. Arch Gen Psychiatry 48:407-413

Hris EW, Ganong AH, Cotman CW (1984): Long term potentiation in the hippocampus involves activation of $\mathrm{N}$-methyl-D-aspartate receptors. Brain Res 323:132-137

Hey I, Murray RM(1990): Why Kraepelin was wrong. The neurodevelopmental view of dementia praecox. In Stefanis, CN, Rabavilas AD, Soldatos ER (eds), Psychiatry: A World Perspective, Vol 1. Amsterdam, Excerpta Medica, pp 223-234

Hruey I, Williams M, Toone BK, Lewis SW, Turner SW, McGuffon P (1990): The ventricular-brain ratio (VBR) in functional psychoses: The relationship of lateral ventricular and total intracranial area. Psychol Med 20:55-62

Pirvey I, Ron MA, Du Boulay G, Wicks D, Lewis S, Murray
RM (1992): Diffuse reduction of cortical volume on magnetic resonance imaging. Psychol Med (In press)

Hays SE, Houston SH, Beinfeld MC, Paul SM (1981): Post natal ontogeny of cholecystokinin receptors in rat brain. Brain Res 213:237-241

Huber G (1957): Pneumoencephalographische und Psychopathologische Bilder Bei Endogen Psychosen. Berlin, Springer-Verlag

Huber G, Gross G, Schuttler R (1975): A long term follow-up study of schizophrenia: Psychiatric course of illness and prognosis. Acta Psychiatr Scand 52:49-57

Illowsky B, Juliano DM, Bigelow LB, Weinberger DR (1988): Stability of CT scan findings in schizophrenia. J Neurol Neurosurg Psychiatry 51:209-213

Ingvar DH, Franzen G (1974): Distribution of cerebral activity in chronic schizophrenia. Lancet II:1484-1486

Jacobi W, Winkler H (1927): Encephalographische studien an chronisch schizophrenen. Arch Psychiatr Nervenkr 81:299-332

Jakob H, Beckmann H (1986): Prenatal developmental disturbances in the limbic allocortex in schizophrenics. J Neural Transm 65:303-326

Jeste DV, Lohr JB (1989): Hippocampal pathologic findings in schizophrenia: A morphometric study. Arch Gen Psychiatry 46:1019-1024

Johnstone EC, Crow TJ, Frith CD, Husband J, Kreel L (1976): Cerebral ventricular size and cognitive impairment in chronic schizophrenia. Lancet II:924-926

Johnstone EC, Owens DGC, Crow TJ, Frith CD, Alexandropolis K, Bydder G, Colter N (1989a): Temporal lobe structure as determined by nuclear magnetic resonance in schizophrenia and bipolar affective disorder. J Neurol Neurosurg Psychiatry 52:736-741

Johnstone EC, Owens DGC, Bydder GM, Colter N, Crow TJ, Frith CD (1989b): The spectrum of structural brain changes in schizophrenia: Age of onset as a predictor of cognitive and clinical impairments and their cerebral correlates. Psychol Med 19:91-103

Jones P, Murray RM (1991): The genetics of schizophrenia is the genetics of neurodevelopment. Br J Psychiatry 158:615-623

Kerwin R, Murray RM (1992): The developmental neurochemistry of medial temporal lobe anomaly in schizophrenia. Schizophr Res 7:1-12

Kerwin R, Patel S, Meldrum B (1990): Quantitative autoradiographic analysis of the glutamate receptor in the hippocampal formation in normal and schizophrenic brain postmortem. Neuroscience 39:25-32

Kleinschmit AMF, Bear MF, Singer W (1987): Blockade of "NMDA" receptors disrupts experience dependent plasticity of kitten striate cortex. Science 238:355-358

Klippel M, Lhermitte J (1909): Un cas de demence precoce a type catatonique avec autopsie. Rev Neurol 17:157-158

Kovelman JA, Scheibel AB (1984): A neurohistological correlate of schizophrenia. Biol Psychiatry 19:1601-1621

Lempke R (1935): Unntersuchungen uber die soziale Prognose der schizophrenic unter besdonerer Berucksichtigung des encelphalographischen Befundes. Arch Psychiatr Nervenkr 104:89-136 
Lewis SW, Murray RM (1987): Obstetric complications, neurodevelopmental deviance, and risk of schizophrenia. J Psychiatry Res 21:413-421

Lewis SW, Chitkara B, Reveley AM, Murray RM (1987): Family history and birthweight in $\mathrm{MZ}$ twins concordant and discordant for psychosis. Acta Genet Med Gemellol 36:267-273

Lewis SW, Murray RM, Owen MJ (1989): Obstetric complications in schizophrenia. Methodology and mechanisms. In Schultz SC, Tamminga CA (eds), Schizophrenia: Scientific Progress. New York, Oxford University Press, pp 56-69

Lewis SW, Harvey L, Ron M, Murray RM, Reveley AM (1990): Can brain damage protectagainst schizophrenia? Br J Psychiatry 157:600-603

Lewis SW, Ford RA, Syed GW, Reveley AM, Toone BK(1992): A controlled study of 99Tc-HMPAO single photon emission imaging in chronic schizophrenia. Psychol Med 22: $27-35$

Liddle PF, Friston KJ, Frith CD, Hirsch SR, Jones T, Frackowiack RSJ (1992): Patterns of cerebral blood flow in schizophrenia. Br J Psychiatry 160: 179-186

Lyeth BG, Jenkins LW, Hamm RJ, Dixon E, Phillips LL, Clifton GL, Young HF, Hayes RL (1989): Pretreatment with MK801 reduces behavioural deficits following traumatic brain injury. Soc Neurosci Abstracts 15:113

Martinot J-L, Peron-Magnan P, Huret JD, Mazoyer B, Baron JC, Boulenger JP, Loc'h C, Maziere B, Caillard V, Loo H, Syrota A (1990): Striatal D2 dopaminergic receptors assessed with positron emission tomography and $76 \mathrm{Br}$ bromospiperone in untreated schizophrenic patients. Am J Psychiatry 147:44-50

Martinot J-L, Palliere-Martinot ML, Loc'h C, Hardy P, Poirer M-F, Mazoyer B, Beaufils B, Maziere B, Allilaire J, Syrota A (1991): The estimated density of D2 striatal receptors in schizophrenia - a study with positron emission tomography and $76 \mathrm{Br}$ bromolisuride. Br J Psychiatry 158: 346-350

Mattson MP, Dou P, Kater SB (1988): Outgrowth regulating actions of glutamate in isolated hippocampal pyramidal neurons. J Neurosci 8:2087-2100

Mattson MP, Rychlilc B (1990): Cell culture of cryopreserved human fetal cerebral cortical and hippocampal neurons: Neuronal development and responses to trophic factors. Brain Res 522:204-214

McNeil TF, Cantor-Grade E, Nordstrom LG, Rosenlund T (1993): Head circumference in "preschizophrenic" and control neonates. Br J Psychiatry 162:517-523

McNeil TF, Kaij L (1978): Obstetric factors in the development of schizophrenia-complications in the births of preschizophrenics and in reproduction by schizophrenic parents. In Wynne LC, Cromwell RL, Matthysse S (eds), The Nature of Schizophrenia. New York, John Wiley \& Sons, pp. 401-429

Mednick SA, Machon RA, Huttunen MO, Bonett D (1988): Adult schizophrenia following prenatal exposure to an influenza epidemic. Arch Gen Psychiatry 45:189-192

Murray RM, O'Callaghan E (1991): The congenital and adult onset psychoses: Kraepelin lost-Kraepelin found. In Kerr A, McLelland H (eds), Concepts of Mental Disorder. London, Gaskell, pp 48-65
Murray RM, Lewis S, Reveley AM (1985a): Towards an at tiological classification of schizophrenia. Lancet II: 1023-1026

Murray RM, Reveley AM, Reveley MA, Shur E, Lewis S (1985b): Genes and Environment in Schizophrenia. In Sakai T, Tsuboi T (eds), Genetic Aspects of Human Behaviour. Tokyo, Igaku-Shoin, pp 63-74

Murray RM, Lewis SW, Owen MJ, Foerster A (1988): The neurodevelopmental origins of dementia praecox. In Bebbington P, Mcguffin P (eds), Schizophrenia: The Major Issues. London, William Heinmann, pp 90-107

Nasrallah HA, Jacoby CG, McCalley-Whitters M, Kuperman $S$ (1982): Cerebral ventricular enlargement in subtypes of chronic schizophrenia. Arch Gen Psychiatry 39: 774-777

Nowakowski RS (1987): Basic concepts of CNS development. Child Dev 58:568-595

O'Callaghan E, Larkin C, Redmond O, Stack J, Ennis JT, Waddington JL (1988): Early onset schizophrenia after teenage head injury. Br J Psychiatry 153:394-396

O'Callaghan E, Gibson T, Colohon C (1990): Seasonality in schizophrenia, confinement of winter birth to patients without a family history. Br J Psychiatry 158:764-769

O'Callaghan E, Sham P, Glover G, Takei N, Murray R (1991): Schizophrenia after prenatal exposure to the 1959 A2 influenza epidemic. Lancet 377:1248-1250

Owen MJ, Lewis SW, Murray RM (1989): Family history and cerebral ventricular enlargement in schizophrenia: A case control study. Br J Psychiatry 154:629-634

Pakkenberg B (1987): Post mortem study of chronic schizophrenic brains. Br J Psychiatry 151:744-752

Perry RH, Dockray GJ, DimalineR, Perry EK, Blessed G, Tomr linson BE (1981): Neuropeptides in Alzheimers disease, depression and schizophrenia. J Neurol Sci 51:465-47/

Pilowsky L, Murray RM (1991): Why don't preschizophrenix children have delusions and hallucinations? Brain Behav Sci $14: 41-42$

Pilowsky LS, Costa DC, Ell PJ, Verhoeff NPLG, Murray RM, Kerwin RW (1993): D2 dopamine receptor binding in the basal ganglia of antipsychotic free schizophrenic patients - a 123I IBZM single photon emission tomogra phy (SPET) study. Br J Psychiatry (in press).

Reveley MA, Chitkara B (1985): Subgroups in schizophrenia. Lancet I:1503

Reveley AM, Reveley MA, Clifford CA, Murray RM (1982): Cerebral ventricular size in twins discordant for schizophrenia. Lancet I:540-541

Reynolds GP (1983): Increased concentrations and laterd asymmetry of amygdala dopamine in schizophrenia. $\mathrm{Nz}$ ture 305:527-529

Reynolds GP, Czudek C, Bzowej N, et al (1987): Dopamine receptor asymmetry in schizophrenia. Lancet I:979

Roberts GW, Ferrier IN, Lee Y, Crow TJ, Johnstone EC, Owens DGC, Bacarese-Hamilton AJ, McGregor G O'Shaughnessey D, Polak JM, Bloom SR (1983): Peptides the limbic lode and schizophrenia. Brain Res 288:199-211

Roberts GP, Woodharms PL, Polak JM, Crow TJ (1984): Dis tribution of neuropeptides in the limbic system of the rat The hippocampus. Neuroscience 11:35-77 
lberts GW, Colter N, Lofthouse R, Johnstone EC, Crow TJ (1987):Is there gliosis in schizophrenia? Investigation in the temporal lobe. Biol Psychiatry 22:1450-1468

Stheibel AB, Conrad A, Sanders VC (1991): An animal model of the schizophrenic hippocampus: An attempt to influence fetal hippocampal development by means of maternal viral infection. Schizophr Res 4:359-360

Shoulz SC, Koller MM, Kishore PR, Hamer RM, Gehl JJ, Friedel RO (1983): Ventricular enlargement in teenage patients with schizophrenia spectrum disorder. Am J Psychiatry 140:1592-1595

m PC, O'Callaghan E, Takei N, Murray GK, Hare EH, Murray RM (1991): Increased risk of schizophrenia following prenatal exposure to influenze epidemics. (submitted for publication).

Sivens IR (1982): Neuropathology of schizophrenia. Arch Gen Psychiatry 39:1131-1139

Soddth RL, Christison GW, Torrey EF, Casanova MF, Weinberger DR (1990): Anatomical abnormalities in the brains of monozygotic twins discordant for schizophrenia. $\mathrm{N}$ Engl J Med 322:789-794

Iner SW, Toone BK, Brett-Jones JR (1986): Computerised tomographic scan changes in early schizophrenia. Preliminary findings. Psychol Med 16:219-225

MA, Sacchetti E, Valvassori G, Cazzullo CL (1988): Brain morphology in schizophrenia: a 2-5 year CT scan followup study. Acta Psychiatr Scand 78:618-621
Waddington JL, O'Callaghan E, Larkin C (1990): Physical anomalies and neurodevelopmental abnormality in schizophrenia: New clinical correlates. Schizophr Res 3:90 (Abstract)

Weinberger DR (1987): Implications of normal brain development for the pathogenesis of schizophrenia. Arch Gen Psychiatry 44:660-669

Weinberger DR, Cannon-Spoor E, Potkin SG, Wyatt RJ (1980): Poor premorbid adjustment and CT scan abnormalities in chronic schizophrenia. Am J Psychiatry 137:1410-1413

Weinberger DR, De Lisi LE, Neophytides AN, Wyatt RJ(1981): Familial aspects of CT scan abnormalities in chronic schizophrenic patients. Psychiatry Res 4:65-71

Weinberger DR, Berman KF, Zec RF (1986): Physiological dysfunction of dorsolateral prefrontal cortex in schizophrenia I. regional cerebral blood flow (rCBF) evidence. Arch Gen Psychiatry 43:114-125

Wernicke C (1900): Grundriss der Psychiatrie Johannes Barth. Leipzig, Druck Von Fischer and Wittig

Williams AO, Reveley MA, Kolakowska T, Ardern M, Madelbrote BM (1985): Schizophrenia with good and poor outcome. II: Cerebral ventricular size and its clinical signifcance. Br J Psychiatry 146:239-246

Winkelman NW, Book MH (1949): Observations on the histopathology of schizophrenia. Am J Psychiatry 105: 889-896 